OBJECTIVE: To determine whether sodium nitroprusside causes fetal death in pregnancies complicated with hypertension.

DATA SOURCES: Medical Literature Analysis and Retrieval System Online (MEDLINE; 1996 to 2003), Excerpta Medica (EMBASE; 1970 to 2003), Web of Science/Institute for Scientific Information (ISI; 1945 to 2003), Literatura Latino-Americana e do Caribe em Ciências da Saúde (LILACS; 1982 to 2003) and the Cochrane Library.

REVIEW METHODS: The medical subject headings used were "nitroprusside and pregnancy", "hy pertension or eclampsia or preeclampsia" and "nitroprusside and pregnancy and hypertensive emergencies". The search was limited to human and female gender, in all fields, publication types, languages and subsets. Articles were also identified by reviewing the references of articles and textbooks on hypertension and pregnancy.

RESULTS: The search located nine studies. The sum of all the publications yielded a total of 22 patients and 24 exposed fetuses (two pairs of twins). There were no randomized clinical trials and no prospective cohorts. All of the studies were observational in nature.

CONCLUSIONS: At present, there is insufficien evidence for definitive conclusions about any direct association between sodium nitroprusside use and fetal demise.

KEY WORDS: Nitroprusside. Fetal death. Feta mortality. High-risk pregnancy. Hypertension.

\section{Does sodium nitroprusside kill babies? A systematic review}

\author{
Obstetrics Department of the Universidade Federal de São Paulo \\ - Escola Paulista de Medicina (Unifesp-EPM), São Paulo, Brazil
}

\begin{abstract}
Hypertensive disorders are a leading cause of maternal and perinatal morbidity and mortality worldwide. A large population-based study ${ }^{1}$ quantified the risk of fetal growth restriction and stillbirths in pregnancies with hypertensive disorders. After controlling for potential confounding factors, the risk of fetal death was 1.4 times greater $(95 \%$ confidence interval, CI: $1.1-1.8 ; p=0.02)$ in women with any hypertensive disorder and 3.2 times greater (95\% CI: 1.9-5.4; $\mathrm{p}<0.001$ ) in those with pre-existing hypertension, in comparison with normotensive women.

Hypertensive emergencies are frequent,
\end{abstract} and are associated with substantial maternal and perinatal morbidity and mortality. Although hypertension is a common denominator, the pathogenesis, clinical features and clinical course are variable and somewhat distinct. ${ }^{2,3}$ Table 1 presents the possible clinical manifestations and consequences of hypertensive crises during pregnancy. Once diastolic blood pressure reaches $110 \mathrm{mmHg}$, there is a general consensus that the patient should receive antihypertensive drugs in a hospital. The medications used in this situation may affect the fetus indirectly, through their effect on uteroplacental perfusion, or directly, after crossing the placenta and entering the fetal circulation. ${ }^{4}$

So far, there has not been any clear evidence indicating that any specific antihypertensive agent is superior. Hydralazine is a popular first choice, but clinical experience with nifedipine and labetalol is mounting. According to a recent systematic review, ${ }^{4}$ except for diazoxide and ketanserin (which should be avoided), the choice of which specific antihypertensive drug to use should be based mainly on the experience of the individual clinician.

There is a need to consider sodium nitroprusside (SNP) in this respect. There seems to be a general impression that SNP is lethal to the fetus, although there may be some doubt about this. On the other hand, there is uncertainty regarding the strength of the evidence for banning its use in clinical practice. The aim of the present study was to review the available clinical data relating to the use of SNP in pregnant women with hypertensive crises.

METHODS

Searches to locate articles relating to the clinical use of SNP during pregnancy were conducted in Medical Literature Analysis and Retrieval System Online (MEDLINE; 1996 to 2003), Excerpta Medica (EMBASE; 1970 to 2003), Web of Science/Institute for Scientific Information (ISI; 1945 to 2003), Literatura Latino-Americana e do Caribe em Ciências da Saúde (LILACS; 1982 to 2003) and the Cochrane Library. The medical subject headings used were "nitroprusside and pregnancy", "hypertension or eclampsia or preeclampsia" and "nitroprusside and pregnancy and hypertensive emergencies". The search was limited to humans and female gender, in all fields, publication types, languages and subsets. Articles were also identified by reviewing the references of articles and textbooks on hypertension and pregnancy.

Table 1. Clinical manifestations and consequences of hypertensive emergencies in pregnancy

Acute aortic dissection
Acute renal failure
Angina pectoris
Eclampsia
Hypertensive encephalopathy
Microangiopathic hemolytic anemia
Myocardial infarction
Pulmonary edema

Adapted from Varon and Marik (2000).2 
Table 2. Use of sodium nitroprusside (SNP) in pregnancy: case reports

\begin{tabular}{|c|c|c|c|c|c|c|c|}
\hline Author & gestational age & clinical findings & drugs before SNP & $\begin{array}{c}\text { no. of } \\
\text { fetuses }\end{array}$ & $\begin{array}{c}\text { total SNP dose } \\
\text { used }\end{array}$ & $\begin{array}{c}\text { duration of SNP } \\
\text { use }\end{array}$ & fetal outcome \\
\hline Paull, $1975^{5}$ & nd & $\begin{array}{l}\text { severe } \mathrm{PIH}, \\
\text { renal failure, } \\
\text { coagulopathy }\end{array}$ & diazoxide & 1 & nd & nd & liveborn \\
\hline $\begin{array}{c}\text { Donkin et al., } \\
1978^{\circ}\end{array}$ & 7 months & $\begin{array}{l}\text { intracranial } \\
\text { aneurysm }\end{array}$ & $\begin{array}{l}\text { diazepam } \\
\text { atropine }\end{array}$ & 1 & $12.5 \mathrm{mg}$ & nd & $\begin{array}{l}\text { liveborn } \\
3200 \mathrm{~g}\end{array}$ \\
\hline \multirow{3}{*}{$\begin{array}{c}\text { Rigg and } \\
\text { McDonogh, } \\
1981^{7}\end{array}$} & 20 weeks & intracranial & propranolol & 1 & $90.0 \mathrm{mg}$ & 96 hours & liveborn \\
\hline & & aneurysm & methyldopa & & & & $3570 \mathrm{~g}$ \\
\hline & 20 weeks & $\begin{array}{l}\text { intracranial } \\
\text { aneurysm }\end{array}$ & nd & 1 & $60.0 \mathrm{mg}$ & nd & $\begin{array}{l}\text { liveborn } \\
3205 \mathrm{~g}\end{array}$ \\
\hline \multirow[t]{4}{*}{$\begin{array}{c}\text { Stempel et al., } \\
1982^{8}\end{array}$} & 38 weeks & severe $\mathrm{PIH}$ & $\begin{array}{l}\text { magnesium sulfate } \\
\text { hydralazine }\end{array}$ & 2 & $0.483 \mathrm{mg} / \mathrm{kg}$ & 42.9 hours & $\begin{array}{c}\text { both liveborn } \\
2340 \mathrm{~g}, 2670 \mathrm{~g}\end{array}$ \\
\hline & 26 weeks & severe $\mathrm{PIH}$ & magnesium sulfate & 1 & $0.219 \mathrm{mg} / \mathrm{kg}$ & 38 hours & $\begin{array}{l}\text { liveborn } \\
730 \mathrm{~g}\end{array}$ \\
\hline & 33 weeks & $\begin{array}{c}\text { chronic } \\
\text { hypertension }\end{array}$ & $\begin{array}{l}\text { hydralazine } \\
\text { furosemide }\end{array}$ & 1 & nd & 38 hours & $\begin{array}{l}\text { liveborn } \\
1927 \mathrm{~g}\end{array}$ \\
\hline & 31 weeks & $\begin{array}{l}\text { severe } \mathrm{PIH}, \\
\text { diabetes }\end{array}$ & $\begin{array}{c}\text { magnesium sulfate } \\
\text { hydralazine }\end{array}$ & 1 & $0.525 \mathrm{mg} / \mathrm{kg}$ & 50 hours & $\begin{array}{l}\text { liveborn } \\
1700 \mathrm{~g}\end{array}$ \\
\hline $\begin{array}{l}\text { Willoughby, } \\
1984^{9}\end{array}$ & 16 weeks & $\begin{array}{l}\text { intracranial } \\
\text { aneurysm }\end{array}$ & nd & 1 & $25.0 \mathrm{mg}$ & nd & $\begin{array}{l}\text { liveborn } \\
3340 \mathrm{~g}\end{array}$ \\
\hline $\begin{array}{c}\text { Shoemaker } \\
\text { and Meyer, } \\
1984^{10}\end{array}$ & 24 weeks & $\begin{array}{c}\text { severe } \mathrm{PIH} \\
\text { pulmonary edema }\end{array}$ & $\begin{array}{l}\text { magnesium sulfate } \\
\text { hydralazine }\end{array}$ & 1 & $3.5 \mathrm{mg} / \mathrm{kg}$ & 15 hours & $\begin{array}{c}\text { stillborn } \\
478 \mathrm{~g}\end{array}$ \\
\hline \multirow[t]{8}{*}{ Baker, $1990^{11}$} & 41 weeks & severe $\mathrm{PIH}$ & $\begin{array}{l}\text { labetalol } \\
\text { phenytoin }\end{array}$ & 1 & nd & 36 hours & $\begin{array}{l}\text { liveborn } \\
3630 \mathrm{~g}\end{array}$ \\
\hline & 28 weeks & severe PIH & $\begin{array}{l}\text { hydralazine } \\
\text { phenytoin }\end{array}$ & 1 & nd & 2 hours & $\begin{array}{l}\text { liveborn } \\
830 \mathrm{~g}\end{array}$ \\
\hline & 34 weeks & severe $\mathrm{PIH}$ & $\begin{array}{c}\text { labetalol } \\
\text { hydralazine }\end{array}$ & 2 & nd & 12 hours & $\begin{array}{c}\text { both liveborn } \\
2520 \mathrm{~g}, 2250 \mathrm{~g}\end{array}$ \\
\hline & 35 weeks & severe $\mathrm{PIH}$ & $\begin{array}{c}\text { labetalol } \\
\text { hydralazine }\end{array}$ & 1 & nd & 2 hours & $\begin{array}{l}\text { liveborn } \\
2460 \mathrm{~g}\end{array}$ \\
\hline & 28 weeks & severe $\mathrm{PIH}$ & $\begin{array}{l}\text { labetalol } \\
\text { hydralazine } \\
\text { phenytoin }\end{array}$ & 1 & nd & 1 hour & $\begin{array}{l}\text { liveborn } \\
1324 \mathrm{~g}\end{array}$ \\
\hline & 36 weeks & severe $\mathrm{PIH}$ & $\begin{array}{l}\text { captopril } \\
\text { nifedipine }\end{array}$ & 1 & nd & 4 hours & $\begin{array}{l}\text { liveborn } \\
2400 \mathrm{~g}\end{array}$ \\
\hline & 34 weeks & severe $\mathrm{PIH}$ & hydralazine & 1 & nd & 3 hours & $\begin{array}{l}\text { liveborn } \\
1770 \mathrm{~g}\end{array}$ \\
\hline & 28 weeks & severe PIH & $\begin{array}{l}\text { labetalol } \\
\text { nifedipine }\end{array}$ & 1 & nd & 6 hours & $\begin{array}{l}\text { liveborn } \\
995 \mathrm{~g}\end{array}$ \\
\hline \multirow{3}{*}{$\begin{array}{c}\text { Mendonça et } \\
\text { al., 199412 }\end{array}$} & nd & severe PIH & nd & 1 & nd & nd & stillborn \\
\hline & nd & severe $\mathrm{PIH}$ & nd & 1 & nd & nd & stillborn \\
\hline & nd & severe PIH & nd & 1 & nd & nd & stillborn \\
\hline $\begin{array}{l}\text { Nascimento } \\
\text { and Vale, } \\
1998^{13}\end{array}$ & 34 weeks & $\begin{array}{c}\text { severe PIH } \\
\text { pulmonary edema }\end{array}$ & $\begin{array}{l}\text { hydralazine } \\
\text { nifedipine } \\
\text { furosemide } \\
\text { morphine }\end{array}$ & 1 & $7.0 \mu \mathrm{g} / \mathrm{kg} / \mathrm{min}$ & 3 hours & stillborn \\
\hline
\end{tabular}

nd $=$ not described; $P I H=$ pregnancy-induced hypertension 
RESULTS

The search located nine studies, ${ }^{5-13}$ which are presented in Table 2. The sum of all the publications yielded a total of 22 patients and 24 exposed fetuses (two pairs of twins). There were no randomized clinical trials and no prospective cohorts. All of the studies were observational in nature.

Eighteen women received sodium nitroprusside for severe hypertension and four (in case reports) were being treated for intracranial aneurysms. All the hypertensive patients had previously received at least one other antihypertensive drug.

Only 6 publications mentioned the SNP infusion rate and it was different in all cases. The duration of SNP use ranged from 1 to 96 hours, and was not mentioned in 7 cases. The gestational age ranged from 16 to 41 weeks and fetal weight from $478 \mathrm{~g}$ to $3650 \mathrm{~g}$. For 4 out of 5 stillbirths, there was no information regarding gestational age or fetal weight. All stillbirths occurred among patients with severe hypertension. Many different antihypertensive agents had been used before SNP, and hydralazine was the most frequent. All patients other than those with cerebral aneurysm had other significant clinical problems relating to severe and persistent hypertension.

\section{DISCUSSIDN}

Currently, the most popular drug for treating severe hypertension in pregnancy is hydralazine, probably due to its long record of safety and efficacy. ${ }^{14,15}$ Labetalol and nifedipine have similar hemodynamic effects and are also widely used. ${ }^{16,17}$ Although some reports have indicated that sodium nitroprusside is also effective and safe when infused for short periods and at low doses, ${ }^{18}$ obstetricians rarely prescribe nitroprusside and the experience of its use during pregnancy is very limited.

Sodium nitroprusside is an ultrafast antihypertensive agent that produces arterial and venous vasodilatation, thereby decreasing both preload and afterload. ${ }^{19}$ Because of this effect, SNP is a good choice for treating pulmonary ede$\mathrm{ma}$, even in pregnancy. ${ }^{20}$ It has an action time of one to two minutes and a plasma half-life of three to four minutes. ${ }^{21,22}$ If the infusion is stopped, the blood pressure returns to the pretreatment levels within one to ten minutes. Sodium nitroprusside is more potent than hydralazine for reducing blood pressure ${ }^{23}$ and, because of the decrease in systemic pressure, it significantly reduces blood flow to the kidneys, uterus and placenta. ${ }^{24,25}$ In pregnant and non-pregnant women, SNP also produces more intense uterine artery dilatation than does hydralazine. And while the placental veins of preeclamptic and normotensive women of similar gestational age are equally sensitive to $\mathrm{SNP}$, the effect is greater in preterm pregnancies. ${ }^{26}$ The results from animal studies support the idea that SNP use for hypertensive emergencies deserves reappraisal and its use during general endotracheal anesthesia merits further investigation. ${ }^{27}$ Almost all publications on SNP mention the possible fetal risk due to cyanide toxicity, which was initially demonstrated in animal studies. One of these studies, which was designed to determine the maternal and fetal hemodynamic effects of SNP in normal and hypertensive animal models, ${ }^{28}$ demonstrated that the drug crosses the placenta and that the fetal concentration of cyanide is related to maternal SNP levels. Another experiment reported that five out of eight pregnant ewes exhibited tachyphylaxis to SNP, followed by fetal deaths. ${ }^{21}$ Nevertheless, these authors commented that SNP could be a useful drug for short-term treatment of life-threatening hypertension in patients with severe preeclampsia. They recommended that the mother and fetus should be carefully monitored during the infusion, especially when using doses greater than $0.5 \mu \mathrm{g} / \mathrm{kg}$ per hour. ${ }^{29}$

SNP is metabolized into cyanogens and converted into thiocyanate by thiosulfate sulfurtransferase. ${ }^{30}$ Nitroprusside contains $44 \%$ cyanide by weight, and this is released non-enzymatically from the drug. The amount of cyanide produced depends on the dose administered, and it is metabolized in the liver to thiocyanate, a substance that is one hundred times less toxic than cyanide. Cyanide removal also requires adequate renal function and bioavailability of thiosulfate. ${ }^{31}$ SNP may cause cytotoxicity through the release of nitric oxide, thus leading to lipid peroxidation ${ }^{32,33}$ and the release of cyanide, which interferes with cell respiration. ${ }^{34,35}$ SNP infusion rates greater than $4 \mu \mathrm{g} / \mathrm{kg} / \mathrm{min}$ for as little as two to three hours may lead to cyanide levels that are within the toxic range and, therefore, an infusion of

Table 3. Sodium nitroprusside: doses recommended for clinical use

\begin{tabular}{lc}
\hline Initial dose & $0.3-1.0 \mu \mathrm{g} / \mathrm{kg} / \mathrm{minute}$ \\
Mean dose & $3.0 \mu \mathrm{gg} / \mathrm{minute}$ \\
\hline Maximum dose & $8.0 \mu \mathrm{gg} / \mathrm{kg} / \mathrm{minute}$ \\
If long-term use is necessary & limited to $2.5 \mu \mathrm{g} / \mathrm{kg} / \mathrm{minute}$ \\
(over periods of hours or days) & blood: $100.0 \mu \mathrm{g} / 100 \mathrm{ml}$ \\
Limits of cyanide tolerability & plasma: $8.0 \mu \mathrm{g} / 100 \mathrm{ml}$ \\
\hline
\end{tabular}

Adapted from DEF (2002). ${ }^{37}$ thiosulfate should be used. Doses greater than $10 \mu \mathrm{g} / \mathrm{kg} / \mathrm{min}$ produce cyanide at a far greater rate than human beings can detoxify it. ${ }^{30}$ Table 3 presents the recommendations for clinical use. ${ }^{36}$

Considering the available evidence from animal and human studies, we believe it is impossible to conclude that SNP itself was directly and entirely responsible for the fetal deaths presented. In fact, data from the publications with the lar-gest numbers of severely hypertensive patients suggest that maternal and fetal toxicity may not be a serious concern when SNP is used for short periods in emergency situations. ${ }^{8,11}$ On the other hand, the cases of fetal deaths attributed to SNP are poorly documented. ${ }^{10,12,13}$ First, many authors failed to report important information such as dosage and duration of use of SNP, as well as the cyanide concentration in maternal blood or fetal tissue. Second, in all the cases reported (except study number 12), SNP was never the only drug involved. It was always prescribed for severely hypertensive patients after one or more antihypertensive drugs had failed to reduce blood pressure, thus making it difficult to reach the conclusion that SNP was directly responsible for fetal demise. The risk of perinatal death during hypertensive emergencies is considerable. As pointed out by a systematic review, ${ }^{4}$ the fetal death rate among patients treated with hydralazine was $5 / 122$ (4.1\%), with labetalol 1/76 (1.3\%) and nifedipine 6/75 (8.0\%). Among the 18 patients with severe hypertension who used SNP there was a high rate of stillbirths (5/18 or $27.8 \%$ ), but it is questionable whether, based on such a small sample, it possible to conclude that the risk of fetal death was significantly higher among patients who received SNP.

These results may be due in part to differences in the clinical settings within which each drug was used. SNP was always prescribed for the most severe cases, and after one or more antihypertensive drugs had failed to reduce blood pressure. Therefore, babies whose mothers received SNP were more likely to be severely hypoxic because of their inherent clinical condition. It needs to be considered whether the result would have been the same if SNP had been used as the first choice. It may have been the case that placental function deteriorated and fetal conditions worsened between patient admission and the time when SNP was used. Chance and confounding factors might also be implicated in these results, which were observed in a very number of patients. It is impossible to answer such questions at the moment.

On the basis of the available data, there is insufficient evidence for any reliable recommendation about the use of SNP for severe hypertension in pregnancy. There is insufficient evidence for definitive conclusions about any direct association between SNP use and fetal demise. 
1. Allen VM, Joseph K, Murphy KE, Magee LA, Ohlsson A. The effect of hypertensive disorders in pregnancy on small for gestational age and stillbirth: a population based study. BMC Pregnancy Childbirth. 2004;4(1):17.

2. Henry CS, Biedermann SA, Campbell MF, Guntupalli JS. Spectrum of hypertensive emergencies in pregnancy. Crit Care Clin. 2004;20(4):697-712, ix.

3. Varon J, Marik PE. The diagnosis and management of hypertensive crises. Chest. 2000;118(1):214-27.

4. Duley L, Henderson-Smart DJ, Meher S. Drugs for treatment of very high blood pressure during pregnancy. In: The Cochrane Database of Systematic Reviews, Issue 1; 2007. Available from: http://www. cochrane.org/reviews/en/ab001449.html. Accessed in 2007 (Feb 12).

5. Paull J. Clinical report of the use of sodium nitroprusside in severe preeclampsia. Anaesth Intensive Care. 1975;3(1):72.

6. Donchin Y, Amirav B, Sahar A, Yarkoni S. Sodium nitroprusside for aneurysm surgery in pregnancy. Report of a case. $\mathrm{Br} \mathrm{J}$ Anaesth. 1978;50(8):849-51.

7. Rigg D, McDonogh A. Use of sodium nitroprusside for deliberate hypotension during pregnancy. Br J Anaesth. 1981;53(9):985-7.

8. Stempel JE, O'Grady JP, Morton MJ, Johnson KA. Use of sodium nitroprusside in complications of gestational hypertension. Obstet Gynecol. 1982;60(4):533-8.

9. Willoughby JS. Sodium nitroprusside, pregnancy and multiple intracranial aneurysms. Anaesth Intensive Care. 1984;12(4):358-60.

10. Shoemaker CT, Meyers M. Sodium nitroprusside for control of severe hypertensive disease of pregnancy: a case report and discussion of potential toxicity. Am J Obstet Gynecol. 1984;149(2):171-3.

11. Baker AB. Management of severe pregnancy-induced hypertension, or gestosis, with sodium nitroprusside. Anaesth Intensive Care. 1990;18(3):361-5.

12. Mendonça D, Garcia ACG, Gomes EF, et al. Aspectos terapêuticos da DHEG na Maternidade do Hospital Universitário Lauro Wanderley. [Therapeutics aspects of DHEG in Lauro Wanderley University Hospital]. J Bras Ginecol. 1994;104(3):71-6.

13. Nascimento RWC, Vale NB. Tolerância ao efeito anti-hipertensivo do nitroprussiato de sódio na anestesia para cesariana de paciente eclâmptica. Relato de caso. [Acute tolerance to the anti-hypertensive effect of sodium nitroprusside infusion in eclamptic patient anesthesia. Case report]. Rev Bras Anestesiol. 1998;48(4):278-82.

\section{AUTHOR INFORMATION}

Nelson Sass, PhD. Professor of Obstetrics, Universidade Federal de São Paulo - Escola Paulista de Medicina (Unifesp-EPM), São Paulo, Brazil.

Caroline Harumi Itamoto. Sixth-year medical student, Universidade Federal de São Paulo - Escola Paulista de Medicina (Unifesp-EPM), São Paulo, Brazil.

Marina Pereira da Silva. Sixth-year medical student, Universidade Federal de São Paulo - Escola Paulista de Medicina (Unifesp-EPM), São Paulo, Brazil.

Maria Regina Torloni, MD. Medical staff, Universidade Federal de São Paulo - Escola Paulista de Medicina (Unifesp-EPM) São Paulo, Brazil.

Álvaro Nagib Atallah, MD, PhD. Professor of Evidence-Based Medicine and Director of the Brazilian Cochrane Center Universidade Federal de São Paulo - Escola Paulista de Medicina (Unifesp-EPM), São Paulo, Brazil.

\section{Address for correspondence:}

Nelson Sass

Departamento de Obstetrícia, Hospital São Paulo

Rua Napoleão de Barros, 737

São Paulo (SP) - Brasil - CEP 04024-002

Tel. (+55 11) 5572-2605

(+55 11) 9116-4222

E-mail: nelsonsa.alp@terra.com.br

Copyright @ 2007, Associação Paulista de Medicina
14. Mabie WC. Management of acute severe hypertension and encephalopathy. Clin Obstet Gynecol. 1999;42(3):519-31.

15. Begum MR, Quadir E, Begum A, Akhter S, Rahman K. Management of hypertensive emergencies of pregnancy by hydralazine bolus injection vs continuous drip--a comparative study. Medscape Womens Health. 2002;7(5):1.

16. Vigil-De Gracia P, Montufar-Rueda C, Smith A. Pregnancy and severe chronic hypertension: maternal outcome. Hypertens Pregnancy. 2004;23(3):285-93.

17. Scardo JA, Vermillion ST, Newman RB, Chauhan SP, Hogg BB. A randomized, double-blind, hemodynamic evaluation of nifedipine and labetalol in preeclamptic hypertensive emergencies. Am J Obstet Gynecol. 1999;181(4):862-6.

18. Rey E, LeLorier J, Burgess E, Lange IR, Leduc L. Report of the Canadian Hypertension Society Consensus Conference: 3. Pharmacologic treatment of hypertensive disorders in pregnancy. CMAJ. 1997;157(9):1245-54.

19. Friederich JA, Butterworth JF 4th. Sodium nitroprusside: twenty years and counting. Anesth Analg. 1995;81(1):152-62.

20. Clark SL, Cotton DB, Hankins GDV, Phelan JP. Complications of pregnancy-induced hypertension. In: Clark SL, Cotton DB, Hankins GDV, et al, editors. Handbook of Critical Care Obstetrics. Boston: Blackwell Scientific Publications; 1994. p.123-38.

21. Naulty J, Cefalo RC, Lewis PE. Fetal toxicity of nitroprusside in the pregnant ewe. Am J Obstet Gynecol. 1981;139(6):708-11.

22. Ring G, Krames E, Shnider SM, Wallis KL, Levinson G. Comparison of nitroprusside and hydralazine in hypertensive pregnant ewes. Obstet Gynecol. 1977;50(5):598-602.

23. Wheeler AS, James FM 3rd, Meis PJ, et al. Effects of nitroglycerin and nitroprusside on the uterine vasculature of gravid ewes. Anesthesiology. 1980;52(5):390-4.

24. Lieb SM, Zugaib M, Nuwayhid B, et al. Nitroprusside-induced hemodynamic alterations in normotensive and hypertensive pregnant sheep. Am J Obstet Gynecol. 1981;139(8):925-31.

25. Nelson SH, Suresh MS. Comparison of nitroprusside and hydralazine in isolated uterine arteries from pregnant and nonpregnant patients. Anesthesiology. 1988;68(4):541-7.

26. Bobier HS, Smith GN, Pancham SR, Brien JF. Comparative study of sodium nitroprusside induced vasodilation of human placental veins from premature and full-term normotensive and preeclamptic pregnancy. Can J Physiol Pharmacol. 1995;73(8):1118-22.
27. Ellis SC, Wheeler AS, James FM 3rd, et al. Fetal and maternal effects of sodium nitroprusside used to counteract hypertension in gravid ewes. Am J Obstet Gynecol. 1982;143(7):766-70.

28. Fung HL. Clinical pharmacology of organic nitrates. Am J Cardiol. 1993;72(8):9C-13C; discussion 14C-15C.

29. Murphy C. Hypertensive emergencies. Emerg Med Clin North Am. 1995;13(4):973-1007.

30. Pasch T, Schulz V, Hoppelshauser G. Nitroprusside-induced formation of cyanide and its detoxication with thiosulfate during deliberate hypotension. J Cardiovasc Pharmacol. 1983;5(1):77-85

31. Hall VA, Guest JM. Sodium nitroprusside-induced cyanide intoxication and prevention with sodium thiosulfate prophylaxis. Am J Crit Care. 1992;1(2):19-25; quiz 26-7.

32. Nakamura Y, Yasuda M, Fujimori H, Kiyono M, Pan-Hou H.. Cytotoxic effect of sodium nitroprusside on PC12 cells. Chemosphere. 1997;34(2):317-24.

33. Gobbel GT, Chan TY, Chan PH. Nitric oxide and superoxidemediated toxicity in cerebral endothelial cells. J Pharmacol Exp Ther. 1997;282(3):1600-7.

34. Niknahad H, O'Brien PJ. Involvement of nitric oxide in nitroprusside-induced hepatocyte cytotoxicity. Biochem Pharmacol. 1996;51(8):1031-9.

35. Izumi Y, Benz AM, Clifford DB, Zorumski CF. Neurotoxic effects of sodium nitroprusside in rat hippocampal slices. Exp Neurol. 1993;121(1):14-23.

36. Dicionário de Especialidades Farmacêuticas: DEF 2001/02. 30 ed. Rio de Janeiro: Editora de Publicaçōes Científicas; 2001.

Sources of funding: None

Conflict of interest: None

Date of first submission: March 6, 2006

Last received: March 2, 2007

Accepted: March 2, 2007

\section{O nitroprussiato de sódio causa óbito fetal? Uma revisão sistemática}

OBJETIVOS: Resolver a questão: o nitroprussiato de sódio causa morte fetal em gestações complicadas por hipertensão?

FONTES DE INFORMAÇÃO: Medical Literature Analysis and Retrival System Online, MEDLINE (1996 a 2003), Excerpta Medica, EMBASE (1970 to 2003), Web of Science - Institute for Scientific Information, ISI (1945 a 2003), Literatura Latino-Americana e do Caribe em Ciências da Saúde, LILACS (1982 a 2003) e a Cochrane Library.

MÉTODO DE REVISÃO: Os descritores usados foram "nitroprussiato e gravidez", "hipertensão ou eclâmpsia ou pré-eclâmpsia", "nitroprussiato e gravidez e emergências hipertensivas" limitada a humanos e mulheres, em todos os campos, tipos de publicação, línguas e subgrupos. Foram também identificados artigos através das referências das publicações e de livros sobre hipertensão e gravidez.

RESULTADOS: A revisão identificou nove publicações. A soma de todas elas descreveu um total de 22 mulheres e 24 fetos (duas gestações gemelares) expostos ao nitroprussiato. Não foram localizados ensaios clínicos randomizados ou coortes prospectivas. Todos os estudos eram do tipo descritivo.

CONCLUSÕES: No momento, não existem evidências suficientes para se chegar à conclusão definitiva de que exista uma associação direta entre o uso de nitroprussiato de sódio e morte fetal.

PALAVRAS-CHAVE: Nitroprussiato. Morte fetal. Mortalidade fetal. Gravidez de alto risco. Hipertensão. 